УДК $316.6+364.2$

Н. І. Кривоконь, д. психол. н., профресор

\title{
СТАНДАРТИ ТА РЕГЛАМЕНТИ СУПЕРВІЗІЇ В СОЦІАЛЬНІЙ РОБОТІ
}

Актуальність теми дослідження. Актуальність розвитку уявлень про супервізію як складову та важливу умову успішного реформування вітчизняної системи соціальних послуг зумовлена введенням в дію нового Закону України «Про соціальні послуги».

Постановка проблеми. Для багатьох соціальних працівників супервізія залишається досить незрозумілою, такою, що викликає внутрішній спротив і напруження, технологією. Важливим завданням в межах рефрормування системи соціальних послуг, $є$ розвиток уявлень про правила, стандарти та особливості організації та проведення супервізї.

Аналіз останніх досліджень і публікацій. В статті згадуються роботи науковців, котрі розвивають підходи до розуміння супервізії, їі сутності, різних фоорм і моделей, аналізують бар'єри і ресурси цієї діяльності, розглядають міжнародні стандарти супервізії, окреслюють вимоги до кваліфрікації супервізора тощо.

Виділення недосліджених частин загальної проблеми. Залишаються поза увагою питання щодо аналізу особливостей цього виду діяльності в контексті технології ведення випадку, а також висвітлення сучасних існуючих регламентів, котрі визначають ціннісні, деонтологічні, процесуальні й правові аспекти супервізії та особливості взаємодії ії суб'єктів.

Постановка завдання. Метою публікації є розширення наукових уявлень про стандарти супервізії як складову кейс менеджменту.

Виклад основного матеріалу. Розглянуто роль супервізії в контексті технології ведення випадку. Представлено анотований огляд міжнародних стандартів супервізї, що визначають їі зміст і процедури проведення. Охарактеризовано цінності й принципи супервізії заідно вітчизняних документів.

Висновки. При розробці вітчизняних стандартів супервізії у соціальній роботі важливо враховувати регламентацію іï адміністративного, навчального та підтримуючого компонентів, а також те, що вона має базуватися на гуманістичних цінностях, конфріденційності та повазі.

Ключові слова: супервізія в соціальній роботі; стандарти супервізії; рефрормування соціальних послуг.

N. I. Kryvokon, Doctor of Psychology, Professor

\section{STANDARDS AND REGULATIONS OF SUPERVISION IN SOCIAL WORK}

Urgency of the research. The urgency of developing ideas about supervision as a component and condition for successful reformation of the domestic social services system is due to the introduction of the new Law of Ukraine "On Social Services".

Target setting. For many social workers supervision remains a rather confusing technology, one that causes internal resistance and tension. An important task within the reformation of the social services is the development of ideas about the rules, standards and features of the organization and conduction of supervision.

Actual scientific researches and issues analysis. The article mentions the work of scientists, who develop approaches to supervision understanding its essence, various forms and models, analyze barriers and resources of this activity, consider international standards of supervision, outline the requirements for the qualification of the supervisor, etc.

Uninvestigated parts of general matters defining. The analysis of the peculiarities of this type of activity in the context of case technology as well as the coverage of modern existing regulations which determine the value, procedural and legal aspects of supervision and the peculiarities of interaction of its subjects, are uninvedtigated.

The research objective. The purpose of the publication is to expand scientific ideas about 
standards of supervision as a component of case management.

The statement of basic materials. The role of supervision in the context of case management technology is considered. An annotated overview of international supervision standards that determine its content and procedures is presented. Values and principles of supervision according to domestic documents are described.

Conclusions. During developing national standards of supervision in social work, it is important to take into account the regulation of its administrative, educational and supportive components as well as the fact that it should be based on humanistic values, confidentiality and respect.

Keywords: supervision in social work; standards of supervision; reformation of social services.

DOI: 10.25140/2412-1185-2019-2(14)-52-59

Актуальність теми дослідження. Актуальність розвитку наукових уявлень про супервізію як складову та важливу умову успішного реформування вітчизняної системи соціальних послуг зумовлена, передусім, введенням в дію 31 січня 2020 року нового Закону України «Про соціальні послуги». Відповідно до п. 18 ст. 1 означеного Закону, супервізія визначається як «професійна підтримка працівників, які надають соціальні послуги, спрямована на подолання профресійних труднощів, аналіз та усунення недоліків, вдосконалення організаційної роботи, стимулювання мотивації до роботи, дотримання етичних норм та стандартів надання соціальних послуг, запобігання виникненню професійного вигорання, забезпечення емоційної підтримки». Беручи до уваги необхідність активізації запровадження супервізії у практику соціальної роботи актуалізуються доробки, присвячені аналізу міжнародних стандартів і вітчизняних нормативних засад стосовно даного, доволі інноваційного за нинішніх обставин, виду діяльності.

Постановка проблеми. Не дивлячись на те, що у 2015 році Міністерством соціальної політики були розроблені й схвалені Методичні рекомендації щодо проведення супервізії у соціальних службах [1], широкого розповсюдження на рівні державних соціальних установ вона все ще не набула. В документі визначено основні цілі, функції та принципи супервізії, стисло описано різновиди та порядок ії проведення, представлено вимоги до супервізорів і зразки документації, в якій можуть фіксуватися ії результати. Проте, для значної частки соціальних працівників і соціальних служб, де вони працюють, супервізія залишається досить незрозумілою, такою, що викликає внутрішній спротив і напруження, технологією. Найчастіше фахівці побоюються супервізорів, ставляться до них насторожено, іноді й упереджено, оскільки не розуміють ні значення, ні можливостей, ні істинних завдань супервізії. Відтак, важливим завданням в межах реформування системи соціальних послуг на основі технології ведення випадку (в міжнародному дискурсі - технології кейс менеджменту), $є$ розвиток уявлень про правила, стандарти та особливості організації та проведення супервізії. Така інфоормація уможливить розширення світоглядних і професійних позицій соціальних працівників і слугуватиме надійним способом розвитку їх професійних компетенцій, а також сприятиме отриманню дієвої підтримки й допомоги при здійсненні реформ.

Аналіз останніх досліджень і публікацій. На разі тематика висвітлення різноманітних аспектів супервізії в соціальній роботі усе частіше виступає предметом дослідження вітчизняних і зарубіжних авторів. Зокрема, науковці розвивають індивідуальний, груповий та організаційний підходи до розуміння супервізії [2], описують сутність та особливості основних положень щодо функціонування різних фрорм і моделей цієї діяльності [3; 4], піднімають питання бар'єрів і ресурсів супервізії [5], аналізують можливості супервізії для досягнення психологічного благополуччя соціальних працівників [6] тощо. Особливий інтерес у контексті проблематики даної публікації, представляє робота О. Савчук, І. Миргородської [7], в якій авторки розглянули стандарти та принципи проведення супервізії в соціальній роботі та окреслили вимоги до кваліфікації супервізора. Зокрема, у статті йдеться про деякі міжнародні підходи, що підтримуються Асоціаціями соціальних працівників деяких країн, і формують етично-ціннісне поле для здійснення супервізії, а також деталізуються основні компетенції супервізорів відповідно до встановлених стандартів.

Виділення недосліджених частин загальної проблеми. Не дивлячись на зростання наукового інтересу до проблем запровадження супервізії в царині вітчизняної соціальної роботи, залишаються поза увагою питання, що стосуються аналізу особливостей цього виду діяльності в 
контексті реформування системи надання соціальних послуг і технології ведення випадку (кейс менеджменту). Не менш важливим уявляється й висвітлення сучасних існуючих норм, котрі визначають ціннісні, деонтологічні, процесуальні й правові аспекти супервізії та особливості взаємодії її суб'єктів. Тим більше, що в Україні до тепер не відпрацьовано чітких, зрозумілих, таких, що відповідають міжнародним стандартам соціальної роботи та сучасним запитам соціальних працівників моделей і алгоритмів супервізії. І, позаяк процес стандартизації соціальних послуг в нашій державі все ще триває, визначення базових нормативних засад супервізії сприятиме як для розробки відповідної документації, так і при підготовці соціальних працівників до позитивного прийняття супервізії як необхідної складової кейс менеджменту.

Постановка завдання. В даній публікації маємо на меті на основі аналізу існуючих міжнародних стандартів і вітчизняних нормативних документів щодо супервізії в соціальній роботі, розширити наукові й прикладні уявлення про супервізію як складову кейс менеджменту.

Виклад основного матеріалу. Важливим аспектом супервізії $€$ розгляд іiї з точки зору запровадження нових підходів і соціально-технологічних процесів при організації та наданні соціальних послуг за технологією ведення випадку. Ведення випадку досить складна, насичена багатьма різноманітними процесами й процедурами соціальна технологія, що пояснює необхідність високого рівня професійних компетенцій фахівця, що працює за цією системою. Причому, ці компетенції мають включати розлогі знання правового, організаційного, економічного, психологічного та соціального характеру, розвинуті комунікаційні навички, вміння переконувати клієнтів та впливати на залучених людей, координувати зусилля представників різних організацій, вправно володіти навиками оцінки ситуації та швидкого прийняття рішень, розумітися на особливостях документообігу та різноманітних видах звітності, користуватися комп'ютерною та іншою офісною технікою, знати основи та вміти користуватися спеціально розробленим для кейс менеджменту програмним забезпеченням, не боятися брати на себе відповідальність та вміло розділяти ії з клієнтом, виступати фрасилітатором та медіатором, здійснювати функції адвокації, пошуку й мобілізації ресурсів тощо.

Такий обсяг компетенцій та виконуваної роботи, а також тісний контакт із клієнтами, їх сім'ями, оточенням, іншими задіяними особами та організаціями породжує чималу кількість професійних ризиків у діяльності кейс менеджерів. Саме на мінімізацію та упередження розвитку негативних ситуацій, ризиків, на психологічну підтримку фахівців із соціальної роботи, а також для формування у них адекватних уявлень щодо рівня відповідності їх діяльності стандартам з надання соціальних послуг і спрямована супервізія в системі кейс менеджменту.

Не менш важливим $є$ розуміння ролі супервізії для управління соціальною організацією, що працює за системою кейс менеджменту. Як управлінська технологія супервізія забезпечує збір інформації, моніторинг діяльності, виявлення проблематики серед працівників та в організації в цілому. Результати супервізії певним чином впливають на планування роботи та визначення стратегії організації, сприяють визначенню шляхів вдосконалення роботи. Супервізор, за потреби, допомагає краще довести задачі до підлеглих (завдяки своєму авторитету та обізнаності, більш досконалому володінню психологічними методами впливу); слідкує за дотриманням стандартів соціальної роботи та встановлює, наскільки працівник є успішним у виконанні своїх посадових обов'язків; безпосередньо не керує, але може впливати на деякі організаційні процеси (зокрема - планування); забезпечує підвищення якості послуг та їх ефективність не лише завдяки спонуканню фахівців до професійного вдосконалення, але і передбачає розвиток прагнень працівників дотримуватися стандартів, слідкувати за правильністю своїх дій та відповідністю їх професійним обов'язкам. Ось чому питання стандартів і нормативів для даного виду практики (і надання соціальних послуг в цілому) набуває особливого значення.

Сенс будь-якого стандарту полягає у забезпеченні надійної основи для розробки спільних очікувань по відношенню до тих чи інших продуктів чи послуг. Стандарти включають в себе певні знання, що можуть виступати ефективними інструментами, здатними просунути інновації та підвищити їх результативність. По суті стандарт - це опис узгодженого методу виконання якихось дій, причому цей опис створюється людьми, наділеними великим практичним досвідом та експертними знаннями у своїй галузі.

Значення стандартів для супервізії на думку деяких авторів [8] полягає у забезпеченні як нових, так і досвідчених спеціалістів доступом до якісної супервізії, яка створює можливості для 
їх професійного розвитку, а також дозволяє поповнювати досвід практичної соціальної роботи відповідно до Етичного кодексу соціальних працівників.

Серед причин, що зумовлюють необхідність існування стандартів супервізії, у деяких міжнародних документах також вказуються наступні [9]:

1) Соціальна робота - це регламентована професія з високим ступенем юридичної та етичної відповідальності й практики.

2) Соціальні працівники зобов'язані дотримуватися положень Етичного кодексу, законодавства та політики соціальної організації, в якій вони працюють, та відповідних процедур, передбачених при виконанні ними їх посадових обов'язків. Супервізія має забезпечити контроль за дотриманням цих положень.

3) Доступ до супервізії виступає важливою складовою професійного розвитку та практикою формування потрібних на практиці компетенцій. Теоретична база знань, на якій ґрунтується соціальна робота, продовжує розширюватися, і соціальні працівники повинні залишатися компетентними.

4) Соціальна робота - це складна професія, що здійснюється в умовах, які постійно змінюються. Складність проблематики, з якою стикаються соціальні працівники у своїй буденній діяльності, призвела до збільшення спеціалізації та більшої різноманітності необхідних для успішної роботи знань та навиків. Супервізори покликані допомагати у розширенні компетенцій соціальних працівників.

5) Соціальні працівники працюють в умовах високих очікувань як з боку споживачів, так $\mathrm{i}$ суспільства. 3 іншого боку, існує велика стурбованість через відповідальність та очікування в автономній практиці. Знизити напруження через ці обставини можна шляхом супервізії.

6) Існують великі навантаження та обмежені ресурси - це реальність, яку потрібно враховувати у практиці соціальної роботи.

Отже, в основі стандартів супервізії лежать базові цінності соціальної роботи, з одного боку, а 3 іншого, - положення, спрямовані на регламентацію супервізії як соціальної та/або управлінської технології. Стандарти, за якими мають працювати супервізори у вітчизняних соціальних службах, повинні базуватися як на позитивному міжнародному досвіді, так i відповідати українському нормативному полю.

Стосовно міжнародних підходів до визначення стандартів супервізії, то, вони не мають принципових відмінностей у різних країнах, хоча враховують особливості тих систем соціальної роботи, для яких вони розробляються.

Наприклад, Канадський стандарт супервізії включає 5 основних тез [9]:

1. Супервізія в соціальній роботі ґрунтується на цінностях, етиці та принципах соціальної роботи як профресії.

2. Ті, хто здійснює супервізію в соціальній роботі, визнають владу та повноваження, властиві їхньому становищу й професійним межам на робочому місці, та належним чином повинні реалізувати цю владу й повноваження.

3. Супервізори мають розвивати спеціалізовані знання та вміння в процесі здійснення супервізії соціальних працівників.

4. Супервізори повинні бути належним чином обізнані щодо конкретної сфери соціальної роботи і її практики.

5. Соціальні працівники повинні мати доступ до регулярної, послідовної та структурованої супервізії.

Дещо детальніше описано стандарти супервізії у документах американських асоціацій Національної Асоціації соціальних працівників (NASW - National Association Of Social Workers) та Асоціації департаментів соціальної роботи (ASWB - Association of Social Work Boards ) [10]. Наведемо опрацьований і систематизований нами анотований переклад основних складових означеного стандарту, позаяк це дозволить краще зрозуміти базові положення та змістовні частини супервізії як діяльності. Важливим $є$ й те, що означені стандарти розроблені для організацій, що працюють в системі кейс менеджменту.

1. Контекст супервізії

- супервізори мають бути обізнаними стосовно сфер практичної соціальної роботи, де вони практикують та мати відповідну кваліфрікацію; 
- якщо супервізори проводять свою діяльність у громадах, до яких вони належать, професійні відносини з супервізантами мають бути етично захищеними;

- супервізори повинні розвивати знання про особливості культури (чи крос культури) спільноти/ населення, представники яких виступають клієнтами соціальних служб, де проводиться супервізія;

- в разі здійснення супервізії різними супервізорами у мультидисциплінарній команді, вони можуть обмінюватися досвідом та працювати спільно. Важливо заздалегідь окреслити параметри відносин, інформацію, пріоритети, що визначаються ролями кожного із супервізорів.

2. Проведення супервізї

- важливим етапом є процес укладання угоди між супервізором і соціальною організацією, де здійснюється супервізія. В угоді мають бути окреслені цілі, обов'язки, часові рамки та звітність по супервізії, а також інша важлива інформація, що регламентує діяльність супервізора в конкретних умовах;

- уся інфрормація, отримана в ході супервізії, має бути конфріденційною та приватною, за винятком випадків, коли розголошення передбачено законом;

- ключовими завданнями супервізора виступає професійний розвиток супервізованих, що досягається зокрема і шляхом впливу на їх мислення, світогляд і поведінку. Відтак, сам супервізор, його професійна модель виступає в якості взірця для наслідування;

- супервізори мають бути компетентними та залученими до постійної безперервної освіти. Якщо супервізор недостатньо обізнаний із тією чи іншою сферою практики, він має звернутися за консультацією чи отримати потрібні роз'яснення;

- супервізори повинні знати статути, положення, регулюючі документи, що стосуються практики супервізії;

- у ситуації виникнення стресових ситуацій чи труднощів супервізори мають мати навички самодопомоги чи звертатися до колег за підтримкою.

3. Правові та регулюючі питання

- супервізори певною мірою поділяють відповідальність за послуги, що надаються клієнтам, адже вони покликані забезпечувати належний нагляд за процесом надання послуг;

- відповідальність лежить на супервізорові, якщо він надав неправдиву чи шкідливу інформацію, або якщо його рекомендації принесли шкоду клієнтам;

- супервізор не може здійснювати супервізію для нинішніх чи колишніх членів сім'ї, партнерів, друзів чи інших осіб, з якими він був у близьких стосунках;

- супервізор повинен вміти управляти ризиками, включаючи запобігання розвитку конфліктних та небезпечних для здоров'я ситуацій;

- супервізор повинен вести належну документацію, передбачену угодою про співпрацю або правилами її функціонування, в залежності від юрисдикції соціальної організації. Записи супервізора повинні бути захищені та зберігатися у таємниці;

- у певних (передбачених угодою) випадках, супервізори можуть мати доступ і перевіряти документацію, що дає інформацію про дотримання стандартів соціальної роботи.

4. Етичні питання

- супервізори повинні мати ґрунтовні знання Етичного кодексу соціальних працівників у тій сорері, де вони практикують;

- стосунки із супервізованими мають будуватися на засадах поваги, розуміння, шанобливого ставлення та підтримки. Супервізори мають дотримуватися чутливих меж професійного спілкування та уникати ризиків експлуатації чи завдання шкоди соціальним працівникам і їх клієнтам;

- супервізор має бути в курсі відмінностей між професійною етикою, основними цінностями й особистими моральними переконаннями та допомагати супервізантам розрізняти ці аспекти при прийнятті практичних рішень;

- позаяк процес прийняття рішень є водночас емоційно насиченим і когнітивно складним, супервізори мають вміти так вибудовувати стосунки в ході прийняття рішень, щоб вони базувалися на справедливості, повазі, цінностях, принципах і регламентах, доречних за даних обставин. Важливо правильно прогнозувати можливі наслідки, ризики та вигоди від дій, котрі слідують за прийняттям рішень; 
- важливим завданням супервізії є дотримання професійних меж між супервізованим і його клієнтом, супервізором і супервізованим. Слід суворо слідувати правилу уникати сімейних чи романтичних стосунків із супервізантами;

- позиція супервізора характеризується більш владною орієнтацією по відношенню до супервізованого, що зумовлює необхідність доречно використовувати свої повноваження у стосунках із ним;

- особиста інформація супервізованих не має виступати основним фрокусом професійної взаємодії у супервізії;

- метою супервізора є створення безпечних умов для функціонування супервізованого при взаємодії з ним. Супервізори сприяють встановленню безпечної, неконфліктної атмосфери в організації, де відбувається супервізія;

- супервізор повинен з обережністю використовувати та санкціонувати використання з боку супервізованих альтернативних практик, методів чи способів впливу.

5. Технології

- прогрес сучасних технологій надає чимало можливостей та викликів у відносинах супервізії. Важливо демонструвати виваженість і компетентність у використанні сучасних технологій в процесі супервізії і практики соціальної роботи, дотримуватися принципів конфіденційності та безпеки;

- при застосуванні сучасних комунікаційних технологій для дистанційної супервізії важливо пам'ятати про дотримання тих же принципів супервізії, якими керуються при очній зустрічі.

6. Оцінка і результати супервізії

- оцінка виступає невід'ємною частиною супервізії і має сприяти розвиткові професійності соціальних працівників, вдосконаленню їх професійної практики та майстерності;

- цілі оцінювання полягають у поліпшенні надання послуг клієнтам, підтримування етичних засад практики соціальної роботи;

- супервізор несе відповідальність за належне здійснення оцінки в процесі супервізії. Оцінка має носити етичний характер і базуватися на справедливих і відомих супервізованому критеріях;

- оцінка має включати терміни (дати), прописані цілі, вказівки, критерії, опис процесу проведення процедури;

- інструментами оцінки можуть бути: кейси, описи успішності, бесіди, реалізація планів супроводу клієнтів тощо;

- для успішної оцінки важливим $€$ підтримування постійного, систематичного зворотного зв'язку з супервізованим, діяльність якого підлягає оцінюванню;

- результати оцінки діяльності можуть представлятися як у письмовій, так і в усній формі;

- заключний етап оцінювання має включати обговорення результатів та можливих викликів.

7. Припинення відносин супервізії

- відносини супервізії завершуються, коли досягаються поставлені в угоді цілі;

- до моменту припинення супервізорських стосунків має бути завершене оформлення відповідної документації, підсумкових звітів;

- у разі переходу супервізора до співпраці з іншою організацією він може поступово передавати інформацію про результати своєї роботи іншому супервізору, котрий приходить на його місце.

В цілому, не можна не погодитися із авторами [2], що існуючі підходи до узмістовлення вимог до супервізії та особливостей побудови стосунків із супервізованими повинні зводитися до наступного: 1)дотримання балансу між відповідальністю за належний рівень роботи супервізованого та повагою до його самостійності; 2) прояв належної турботи про благополуччя клієнта та його захист з урахуванням його автономії; 3) дії в межах своєї компетенції, звернення по допомогу за необхідності; 4) лояльність - вірність відкрито чи приховано даним обіцянкам; 5) відмова від використання пригнічуючих дій; 6) відкритість до критики та зворотного зв'язку разом із зобов'язанням продовження освіти.

Ми вже зазначали, що вітчизняні нормативні уявлення про стандарти й алгоритми супервізії для соціальних працівників на разі розвиваються, фрормуються, документуються. Вони базуються на Кодексі етики соціальних працівників і практичних психологів, що окреслює шість основних цінностей та принципів соціальної роботи, а саме: 1) повага до гідності та системи 
цінностей інших людей; 2) досягнення та підтримка соціальної справедливості; 3) служіння людству, спільноті; 4) комплексність надання допомоги у професійній практиці; 5) конфіденційність по відношенню до клієнтів і фрахівців; 6) компетентність у професійній практиці (як відповідальність соціальних працівників стосовно дотримання належного рівня професійної майстерності та досвіду).

Принципи супервізії сприяють усвідомленню важливості процесу професійної супервізії для практики надання соціальних послуг. Основні принципи супервізії в соціальній роботі в Україні представлені у відповідних Методичних рекомендаціях [1], зокрема це мають бути:

- поінформованість: перед проведенням супервізії працівника соціальної служби доцільно поінформувати про цілі й умови проведення супервізії, використання результатів супервізії;

- дотримання етичних норм: під час проведення супервізії особливу увагу слід звертати на дотримання конфіденційності;

- дотримання анти дискримінаційного підходу щодо віку, статі, етнічної, сексуальної та релігійної приналежності працівника;

- регулярність та систематичність супервізії;

- доступність супервізії: кожен працівник соціальної служби має можливість пройти супервізію у разі необхідності (екстрена супервізія) або згідно з планом;

- розподіл відповідальності: доцільно визначити відповідальність супервізора та працівника соціальної служби за впровадження результатів супервізій.

Висновки. Підсумовуючи інформацію стосовно наявних підходів до визначення стандартів супервізії, зазначимо, що усі вони наголошують на необхідності відповідати потребам супервізованого працівника, включаючи адміністративний, навчальний та підтримуючий компоненти, а також базуватися на гуманістичних цінностях, конфіденційності та повазі. Супервізія повинна стати частиною політики організації, і це має відображатися у відповідних положеннях, посадових інструкціях і регламентах. Службові обов'язки супервізора мають бути чітко прописані з урахуванням часу, необхідного для супервізії кожного працівника, регулярності зустрічей, критеріїв оцінювання діяльності, фрормату документування даного процесу, особливостей взаємодії та етики відносин.

\section{Література}

1. Про затвердження Методичних рекомендацій щодо проведення супервізії у соціальних службах: наказ Міністерства соціальної політики України № 5 [Електронний ресурс]. Відомості Верховної Ради України. - № 0005739-15. - 5.01.2015. - Режим доступу до ресурсу : https://zakon.rada.gov.ua/rada/show/v0005739-15\#Text.

2. Астремська, І. В. Прикладні методики та основи супервізії в соціальній роботі : навчальний посібник / І. В. Астремська. - Миколаїв : Вид-во ЧНУ ім. Петра Могили, 2017. - 396 с.

3. Браун, А. Супервізор у соціальній роботі: супервізія догляду в громаді, денних та стаціонарних установах / А. Браун, А. Боурн; пер. з англ. Т. Семигіної. - К. : Унів. вид-во «Пульсари», 2003. - 240 с.

4. Карагодіна, О. Г. Запровадження супервізії у соціальній роботі: бар'єри та ресурси / О. Г. Карагодіна, О. О. Байдарова // Проблеми соціальної роботи: філософрія, психологія, соціологія. - 2014. - № 1 (4). - С. 29 - 36.

5. Кривоконь, Н. І. Наснаження в супервізії: або як зробити щасливішими фахівців із соціальної роботи / Н.І.Кривоконь // Щастя та цивілізаційний розвиток :Тези доповідей міжнародної науково-практичної конфреренції (Львів 14-15 листопада 2019 р.). - Львів : Львівський національний медичний університет імені Данила Галицького, 2019. - C. $131-135$.

6. Савчук, О. М. Стандарти супервізії в соціальній роботі / О. М. Савчук, І. В. Миргородська // Наукові записки НаУКМА. - Том 136. Педагогічні, психологічні науки та соціальна робота. - Київ, 2012. - С. 67-71.

7. Ховкинс, П. Супервизия. Индивидуальный, групповой и организационный подходы / П. Ховкинс, Р. Шохет // СПб : Речь, 2002. - 352 c.

8. Best practice standards in social work supervision. - Washington : Washington National Association of Social Workers, 2013. $-35 \mathrm{p}$.

9. Franséhn, M. The importance of supervision in social work - the example of Sweden [Electronic resource] / M. Franséhn // Göteborg: Göteborg University. - Regime of access : http:// www.eassw.org/regionalSeminars /BRNO/Supervision in social work.pdf.

10. Newfoundland and Labrador Association of Social Workers. Standards for supervision of social work practice (Adopted June 16th, 2011). [Electronic resource]. - Regime of access: https://nlasw.ca/sites/default/files/inlinefiles/Standards_For_Supervision.pdf.

\section{References}

1. Pro zatverdzhennya Metodychnyx rekomendacij shhodo provedennya superviziyi u socialnyx sluzhbax [On approval of Methodical recommendations for supervision in social services]. (2015). zakon.rada.gov.ua. Retrieved from https://zakon.rada.gov.ua/rada/show/v0005739-15\#Text [in Ukrainian].

2. Astremska, I. V. (2017). Prykladni metodyky ta osnovy superviziyi v socialnij roboti [Applied methods and basics of 
supervision in social work]. Mykolayiv: Vyd-vo ChNU im. Petra Mogyly [in Ukrainian].

3. Braun, A., Bourn, A. (2003). Supervizor u sotsialniy roboti: superviziya dohlyadu $v$ hromadi, dennykh ta statsionarnykh ustanovakh [The social work Supervisor: supervision in the community, day care and residential institutions]. Kyiv: Univ. vyd-vo «Pulsary» [in Ukrainian].

4. Karahodina, O. H., Baydarova, O. O. (2014). Zaprovadzhennya superviziyi u sotsialniy roboti: baryery ta resursy [Introduction of supervision in social work: barriers and resources]. Problemy sotsialnoyi roboty: filosofiya, psykholohiya, sotsiolohiya - Problems of social work: philosophy, psychology, sociology, 1(4), 29-36 [in Ukrainian].

5. Kryvokon, N. I. (2019). Nasnazhennia v supervizii: abo yak zrobyty shchaslyvishymy fakhivtsiv iz sotsialnoi roboty [Empowerment in supervision: or how to make social workers happier]. Shchastia ta tsyvilizatsiinyi rozvytok - Happiness and civilization development: Proceeding of International scientific-practical conference. (pp.131-135). Lviv: Lvivskyi nacionalnyi medychnyi universytet imeni Danyla Halytskoho [in Ukrainian].

6. Savchuk, O. M., Myrgorodska, I.V. (2012). Standarty supervizii v sotsialnii roboti [Standards of supervision in social work]. Naukovi zapysky NaUKMA - Scientific notes of NaUKMA, 136, 67-71 [in Ukrainian].

7. Hovkins, P., Shohet, R. (2002). Superviziya. Individualnyy, gruppovoy $i$ organizatsionnyy podkhody [Supervision. Individual, group and organizational approaches]. Saint Petersburg: Rech [in Russian].

8. Best practice standards in social work supervision. (2013). Washington: National Association of Social Workers [in English].

9. Franséhn, M. (2011). The importance of supervision in social work - the example of Sweden. Göteborg University, Sweden. Retrieved from http://www.eassw.org/regionalSeminars/BRNO/Supervision in social work.pdf [in English]

10. Newfoundland and Labrador Association of Social Workersю Standards for supervision of social work practice. (2011). nlasw.ca. Retrieved from https://nlasw.ca/sites/default/files/inline-files/Standards_For_Supervision.pdf [in English].

Надійшла 14.11.2019

Бібліографічний опис для цитування:

Кривоконь, Н. І. Стандарти та регламенти супервізії в соціальній роботі / Н. І. Кривоконь // Проблеми соціальної роботи: фрілософрія, психологія, соціологія. - 2019. - № 2 (14). - С. 52-59. 